\title{
Study on the Construction of New Classroom Teaching System in Colleges Based on Reform of Creative Education
}

\author{
Yanqing Zeng \\ Xi'an Fanyi University, 710105 Xi'an China
}

2876601717@qq.com

Keywords: Creative reform; Higher education; New classroom teaching system

\begin{abstract}
Since the beginning of 21 Century, both the party and government has paid more attention to the education. Higher education is an important part of education in our country, so well implement higher education, carry out targeted training are of vital importance. Based on this, can we continually strengthen the creative consciousness of college students to provide high quality talents for the society. In recent years, with the continuous deepening of the national education system reform, it is very important to strengthen orderly creative education, deepen the education reform and promote quality education. The higher education in our country mainly focused on classroom teaching, so it is significant to establish and improve the classroom teaching system for the development of Higher Education under based on creative education reform.
\end{abstract}

\section{Introduction}

With the continuous deepening of education system reform and the prevalence of quality education, deepening education reform and promoting quality education has become the basic way to improve the quality of talents training. Nowadays, the economy is soaring, and the mission of China's higher education is not only helping students obtain the degree, but also promoting quality education, strengthening the education innovation to cultivate more high quality talents for the society. Since 2015, China has begun to innovate the education of colleges and universities, and the core task of innovative education reform is to cultivate students' creative thinking ability. The key to cultivate students' creative thinking ability is to do a good job in classroom teaching, which is the main process of learning. There are a series of drawbacks of traditional teaching mode which is not conducive to create innovation ability of potential students. Only by completely changing all the disadvantages of traditional classroom can we structure more vital teaching modes.

\section{Analysis on the Importance of Improving and Constructing the New Classroom Teaching System Based on the Reform of Creative Education}

Construction of New Classroom Teaching System in Colleges Is Conducive to Improving Students' Creative Ability. In recent years, in order to improve the quality of education, many colleges and universities have carried out new classroom teaching. The traditional teaching mode does not only make students' thinking ability limited but also restricts their creative thinking ability. The construction of new classroom education system based on the innovation education reform has solved this problem fundamentally, which plays a irreplaceable role to improve student's comprehensive quality and promote the student's employment. Secondly, at present, China is in shortage of innovative talents, and the classroom teaching system is required to provide human resources to construct a creative country. Earlier in the Seventeenth National Congress, both the party and country has cleared the significance of innovative education and pointed out to strive to improve the national capability of independent innovation, and to build our country into a innovative country. At the same time, the core content of the Seventeenth National Congress also includes to suggestion to improve the education career because only by well managing the education career can we cultivate talents and improve the comprehensive national strength.

Construction of the New Classroom Teaching System in Colleges Is Conducive to the Promotion of the Employment of Students. Under the background of creative education reform, 
to construct new classroom teaching system of colleges cannot only improve the students' comprehensive quality, but also promote the employment of college graduates in our country; because only when students comprehensive ability is improved, can they become more adapted to the society. With the deepening education reform, higher education is highlighted, and under such a background, colleges and universities across the country are expanding the enrollment scale. At the same time, the number of undergraduate and graduate student graduate has also increased. According to statistics, the number of college graduates in China has exceeded 7 million 650 thousand, increased by nearly 150 thousand comparing to 2015 , and the growth rate increased by $2 \%$. So the employment situation faced by college graduates becomes more competitive. Therefore, the construction of the new classroom teaching system of colleges and universities is most commonly adopted, especially in the context of deepening of innovation and entrepreneurship education reform. Only by building a perfect teaching system, change the traditional teaching mode can we continue to improve and strengthen students awareness of innovation and entrepreneurship. Actually, the construction of new classroom teaching system is to eventually promote the employment rate of College students.

Construction of New Classroom Teaching System in Colleges Is the Requirement for Innovative Education in Colleges. At present, creative and entrepreneurship education has become a new education model for the continuous reform of the higher education in our country and our country has formed a preliminary teaching system, which is an effective combination between teaching philosophy and mode. In order to promote the deepening of China's higher education innovation reform, we have to fundamentally change the traditional mode of education, improve the traditional teaching mode of classroom and build up a new teaching system. Therefore, the construction of new classroom teaching system of colleges is also the requirement of promoting innovation education in Colleges. For most students, only by building a new type of classroom teaching system, can the majority of students' innovative thinking and innovative ability can be improved. Only in the new class system, students can be bold to use their creative thinking, and creating a good learning environment is beneficial to cultivate innovative talents. What's more, cultivating talents plays a very special role in increasing the economy while the new classroom system construction can help to improve students learning enthusiasm, ignite students' enthusiasm to learn and create a good learning environment.

\section{Shortcomings and Drawbacks of Traditional Classroom Teaching System}

The Single Teaching Method Is the Biggest Drawback of Traditional Classroom Teaching System. Traditional classroom teaching is just book knowledge indoctrination, which lags behind and hamper the development of students' creative thinking ability. What's more, teachers always adopt a teaching method adapted to all students based on traditional teaching mode and one PPT courseware can be used for many years, which is barely changed for years. So, students only learn by rote. More directly, the traditional teaching system let students learn passively and cannot provide opportunities for students to innovate. As a result, students can only memorize things and cannot take the initiative and will lose their independence and creativity.

Traditional Teaching System's Teaching Time Is Fixed, Which Will Restrict Student's Learning. Firstly, traditional classroom teaching time is fixed and each week the class is relatively consistent, which makes students study based on restricted time and is not beneficial to ignite students' imagination. Everyone has different biological clock and some classes are arranged in the afternoon and students won't focus, which will thus affect the teaching quality. Secondly, in traditional classroom, teachers are main bodies and students barely have chance to show themselves. So the class is not active at all while single knowledge infusion will make students tired.

The Traditional Classroom Teaching Plan Is Not Properly Set, Occupying a Lot of Time of Students. For college education, it is very important to do a good job for teaching plan of each term. This is because the teaching plan is course setting which will affect the learning schedule and students' learning efficiency if it is set improperly. At present, many colleges and universities in our country set intense subjects to complete teaching task and they even occupy the time of weekends. 
As a result, students will lose interest on study and wont have time for adjusting. Moreover, intense teaching plan also occupies students' thinking time and they don't have time to digest. After a week learning, students cannot even master the basic idea, which is a drawback.

\section{Analysis on the Construction Strategy of Constructing New Class Teaching System in Colleges Based on Creative Education Reform}

Based on the above situation and problems, colleges should evaluate the construction of college curriculum system with a development view. In the process of constructing a new classroom teaching system, we should continually change ideas, carry out innovation and reform to break the traditional mode and construct the system from multiple levels. Thus, can we change the situation of learning inefficiency.

Change the Traditional Single Teaching Method, Using the Multi Factor Teaching Means. Teachers take the initiative in traditional classroom teaching while students are listening and this single teaching mode is not conducive to the creation of innovative thinking ability and the teaching effect is barely satisfactory. In addition, multi factor teaching cannot solve this shortage fundamentally. So-called multi factor teaching refers to different teaching styles besides traditional course description. To begin with, the role of teachers and students changes; traditional teaching takes teachers as the focus while students don't have opportunities to demonstrate themselves in the class. As a result, it will be very difficult to ignite their imagination and learning passion. By changing the roles, students become dominant while teachers help so they can take the initiative, which is helpful to develop their innovative thinking ability and cultivate their innovative consciousness. Moreover, flipped classroom is also a new teaching mode which can help to release students from classroom and have more time to discuss innovative ideas, and is of vital importance to help students to cultivate abilities to solve problems and carry out independent learning.

Adjust the Teaching Plan, Improve the Quality of Teaching According to the Actual Situation. At present, during the process of constructing college teaching system there are a lot of improper teaching plans. So, colleges should continually integrate the teaching plans and add the proportion of creative and entrepreneurship to cultivate students' innovative ability and at the same time reduce the setting of professional courses. While setting the subjects, we have to try the utmost to let every faculties to participate in and adjust the teaching plan in time so as to help students thoroughly understand. Overall, it is critical to improve teaching efficiency, avoid and reduce repetitive teaching as well as improve teaching quality.

Try Unremitting Efforts to Build a High Quality Teaching Team. Teachers are guiders for students in their academic career, so the comprehensive quality of teachers has an important impact on the development of students. In addition, based on the deepening of creative education reform, the quality of teachers is of great significance for constructing a new system of classroom teaching. Therefore, local colleges and universities must strengthen the cultivation of faculties. For example, some colleges can properly improve the requirement to introduce teachers with better quality and carry out training for those with less knowledge. Moreover, they should hire some experts or famous teachers to guide and give training so as to improve faculties' ability and satisfy the requirement of creative and entrepreneurship education. Furthermore, in order to make up for the shortage of faculties, some colleges can also recruit some scientists, entrepreneurs to do part time so as to continually improve the quality of faculties. Finally, in order to better implement the education, we have to introduce more excellent teachers from various channels to construct a better faculty system, which should be a guarantee to have diversified development of creative education.

\section{Conclusion}

To sum up, in the context of today's rapid social and economic development, it is of vital importance to implement the higher education. In addition, based on the deepening of creative education reform, it is essential to construct new teaching system and colleges should change the traditional teaching mode and continually rich the methods. In addition, they should properly 
introduce teachers with better quality in order to guarantee the sound development of higher education in China.

"Research on Humanistic Concern and Psychological Counseling in the Ideological and Political Education of College Students in Shaanxi Province", A Project funded by the Social Science Foundation of Shaanxi Province, Project No.: 2014M04

\section{References}

[1] Sheng Qunli, Zhong Lijia, Zhang Yumei. University Teachers' teaching design ability-study on university teachers' teaching design ability [J]. Open education research. 2015 (04)

[2] Sun Hui. "Non-classroom teaching", "classroom teaching" difference-discussion on the topic that it is urgent to carry out Non-classroom teaching for college music majors [J]. Education for Chinese After-school

[3] Chen Jingbo, Gao Fude, Chi Wanchang. Clear the basic thought of research and strengthen the scientific management for scientific research [J]. Yunnan University Journal (NATURAL SCIENCE EDITION), 1996 (S1)

[4] Yuan Dingguo, Liu Yongfeng, Liang Jingqing. A systematic analysis on the concept of teaching mode -- the three-dimensional operating mechanism of teaching mode [J]. Journal of Southwestern Normal University (HUMANITIES AND SOCIAL SCIENCES). 2005 (06)

[5] Han Yuxia, Ni Jiang, Gu Hongxi, Li Wenkai, Li Yu, Xu Weilian, Cao Depin. Research and Practice on the comprehensive evaluation and feedback of classroom teaching [J]. Chinese Journal of medical education. 2014 (02)

[6] Wang Dongxu. Research on the monitoring system of college sport evaluation- Based on the idea of fuzzy mathematics and artificial intelligence [J]. sports research and education. 2013 (04)

[7] Zheng Zhu, Wei Jun, Liu Kai. Design of classroom teaching evaluation system in Colleges -case study on Beijing universities' sixth basic teaching skills competition of young teachers [J]. China University teaching. 2010 (08)

[8] Li Pan. Some thoughts on the evaluation of classroom teaching in Colleges [J]. Journal of Shanxi Normal University (SOCIAL SCIENCE EDITION). 2011 (S3)

[9] Lu Shuangpo. The evaluation of college classroom teaching in China [J]. Heilongjiang education (higher education research and evaluation) 2009 (05).

[10]Dong Bijin, Study on the evaluation subject relevance in classroom teaching evaluation -- a case study of experts [J]. Weekly examination, 2015 (51) 